The unique purpose of Worldview is to place public policies, particularly in interna-

\section{Re Fulbright on the Sinai Agreement}

To the Editors: J.W. Fulbright's article "Beyond the Sinai Agreement" (Worldview, December, 1975) continues his astigmatic approach to the political situation in the Middle East in general and of Israel's position there in particular

A study of American foreign policy throughout our entire history makes eminently clear that we typically act out of broad national interests. We do not act because we desire any given nation, including Israel, to survive. We may wish such a nation to survive. but we have never sacrificed strong national interests toward such a goal.

$\mathrm{Mr}$. Fulbright assumes in his article that the Arab oil producers perceive Israel as their feared enemy. He seems to have forgotten that it was Egypt that has in the past threatened Kuwait, that it was Iran that threatened Iraq, that it has been Libya that has challenged various Arab regimes. While one may state that on the rhetorical level Israel is the most feared enemy of all Arab states, this is not true in geopolitical terms. Therefore, when the United States supports Israel, it does so in order to protect our interests in the Mediterranean Basin and to have Israel serve as a buffer against the aggression of some Arab nations against others. Has Mr. Fulbright forgotten that upon the establishment of the State of Israel the armies of Syria, Transjordan, and Egypt marched not in the interest of the Palestinians but in their own interests, and that as a conclusion of that war in 1948 these three nations, as well as Israel, had succeeded in divid ing up Palestine?

It is intriguing that $\mathrm{Mr}$. Fulbright can ignore the social, religious, and economic complexities of Lebanon when he implies that the strife in that embattled nation will be settled with peace between Israel and her neighbors.
The simplistic approach of Fulbright's comments reaches its peak when he writes "that the key to peace in the Middle East is in the internal politics of the United States." Is it possible that he doesn't know or understand the dramatic social, economic, and political problems that are not only a part of the internal situation of every Middle East state but of the varied interests among them? The reductionist approach of $\mathrm{Mr}$. Fulbright, particularly coming from an individual who has held positions of such great importance in the centers of American power, is appalling.

Joseph R. Rosenbloom

Department of Classics

Washington University

St. Louis, Mo

\section{"Thinking Canada"}

To the Editors: The summer reverie of R.J. Neuhaus has produced an Excursus on Canada (Worldview, October, 1975). I used to be a great admirer of his writing. But that obviously was true only as long as he was writing about "them." When he writes about us, his piece strikes me as silly and unnecessarily insulting. So I take pen in hand. Does he touch a sensitive nerve, or is he just talking foolishly?

The article contains inaccuracies. Four are particularly gross.

1. There is no talk in Canada of "excluding" Time and Newsweek from magazine racks. The bill before Parliament would abolish a previous legislation that grants tax privileges to advertisements placed in the Canadian editions of Time and Reader's Digest, the only two U.S.-owned magazines that produce (continued on p. 56) tional affairs, under close ethical scrutiny. The Council on Religion and International Affairs, which sponsors the journal, was founded in 1914 by religious and civic leaders brought together by Andrew Carnegie. It was mandated to work toward ending the barbarity of war, to encourage international cooperation, and to promote justice within all societies. The Council is independent and nonsectarian. Worldview is an important part of the Council's wide-ranging program in pursuit of these above goals.

Worldview is open to diverse viewpoints and encourages dialogue and debate on issues of public significance. It is edited in the belief that large political questions cannot be considered adequately apart from ethical reflection. The opinions expressed in Worldview do not necessarily reflect the positions of the Council. Through Worldview the Council aims to advance the national and international exchange without which our understanding will be dangerously limited.

Philip A. Johnson, Publisher

\section{Editorial Board:}

Hans Morgenthau, Chairman

William J. Barnds

Eugene B. Borowitz

Noel J. Brown

Jorge Dominguez

J. Bryan Hehir

Donald F. McHenry

Paul Ramsey

Seymour Siegel

Paul Sigmund

Kenneth W. Thompson

Howard Wriggins 
Correspondence (from p. 2)

a Canadian edition. The proponents of this new legislation argue that Canadians enjoy writing for each other as well as producing paper for the whole continent and should be able to do so without "unfair" competition from the powerful neighbor. (No one argues in favor of abolishing competition.) Opponents of the proposal believe that Time's tax privileges are fair, since Time, unlike Newsweek, does have editorial pages produced in Canada. Mr. Neuhaus's account of the TV debate is also garbled and oversimplified.

2. The federal government does not support the propositions that all Canada is bilingual. It holds that all Canadians are entitled to the services of the federal government in either English or French. Frenchmen in Saskatchewan create no legal or political problems; like all tourists they will be warmly welcomed. There is, however, a problem about the few francophone Canadians who are settled there. The current policy is that they have the right to file their federal income tax in French or formulate a complaint against the Post Office in French. Those francophone Canadians vacationing in the West will find that the literature in the National Parks in available in their language too. That is about the extent of their "rights." The anglophone mailman in Saskatchewan is not expected to learn French to do his route. If young and bright, he will realize that ability to speak French will be an asset if he wants to aspire to a national role. The mechanisms in volved here are social reward, not legal coercion.

3. French-speaking federal civil servants do not need to be "forced" to learn English. Every survey demonstrates that they already know it. Most French Canadians are digging their heels in, but not about having to learn a second language, for that is a fact of life; they rather insist that in their own country they should be able to function for most of the time in the language which is their own and which they know best.

4. As for the support gained by the separatist movement in Quebec, it reached 26 per cent of the popular vote in the last provincial election (that is something more like 40 per cent of the Quebec francophone vote). The number of available "unreconstructed Gaullists" and "cocktail party champions of the IRA and Puerto Rican independence" cannot account for this percentage. This sort of percentage also impresses me more than acts of terrorism.

Moving to more delicate grounds, it seems t $\rho$ me that Mr. Neuhaus's vision is warped on many points. The mood of "ambivalent admiration" was characteristic of the 1950's, when indeed numerous Canadians went south ("talent that went to the U.S."). Mr. Neuhaus, however, is strangely selective in his outline of what has happened since then. The last decades, for instance, saw the growth of a selfish feeling of being lucky to have been spared some of the U.S. experiences. There has also been a reversal in individual migration: More Americans have come north and sworn allegiance to the Queen than Canadians have gone south to sacrifice on the altars of republicanism. And, to move to the trickiest issue, what is wrong with public schools in any given territory offering their instruction in one maternal language only-with, of course, the teaching of such second language as will be most useful? Peace in multilingual countries is usually achieved through unilingual territoriality. A Swiss can have his children educated in German, French, or Italian, but to exercise this "right" he must move his family to German-, French-, or Italian-speaking areas. Can $\mathrm{Mr}$. Neuhaus name one political unit in the world which, in the name of freedom, undermines its own cultural identity by using tax revenue to support schools which use as a dominant language that of the toughest cultural competitor?

Let me add that the "notorious Bill 22 " endorses the principle of stabilized enrollment in anglophone schools for the anglophone minority, the demographic trends of which are stable. The present Quebec government is strongly committed to this policy, probably in the spirit of quid pro quo, since most anglophone provinces do give now a varying degree of support to their francophone schools. (Needless to say, the Quebec government is under attack for that from its ultranationalists.). So where in all this are the infringements upon democratic notions of freedom?

Let us reserve our democratic indignation for those social systems where school policies do not just show cohesive force but are genuinely totalitarian, where private schools are banned or have insuperable odds against them, where second languages are taught in a manner that weeds out any alien cultural influences, where the possibility of protest through disaffection is denied. Let me finally touch briefly upon one other topic. I welcome anything that prevents Canadians from taking themselves too seriously, but does Mr. Neuhaus really want me to believe that our attempts to pursue a Canadian foreign policy are somewhat akin to the drive to "think snow" in the Vermont hills?

Mr. Neuhaus's ignorance of Canadian economic and social realities also requires attention. On this point, however, I will not attempt to redress but will limit myself to two comments.

1. His diagnosis is stragely selffulfilling. Imagine me trying to document signs of cultural vitality. I would obviously be perceived as involved in "the desperate search for arguments" and simply prove that I belong to the "intellectual industry" that makes believe and thinks Canadian. If I just point to something in Canada that is not "reactive or comparative" to the U.S., I am still proving his point by reacting to his article. With my motives thus impugned, what can I say? Perhaps point out that this game can be played both ways; what $\mathrm{Mr}$. Neuhaus calls "talent seeking opportunity" can also be labeled "going after the bigger salary" (yes, in the 1950's there was a differential) or going where the intellectual excitement seems greatest (in the '50's many small-town anglophone Canadians were sure that large U.S. cities were "where the action is," except that in those days they called it "where the relevant issues are"). Would Mr. Neuhaus care to compare the relative moral dignity of his own existential choice with that of those Canadians who did turn down attractive offers?

Let us move clearly away from this sort of thinking. Can we perhaps agree that there is an equally respectable human endeavor in our different acts of citizenship? Common understand- 
ing, I think, commends such a proposition and not the one about "common sense" being on the side of "joining the Union" and "winsome superstition" on the side of resistance to such views. Few will consciously argue that citizenship in a certain country is an ipso facto basis for moral superiority. (Let me add, however, that only the naive will believe that choosing or maintaining a citizenship is an act that has no moral ramifications.

2. The second comment can be made much more briefly. Ignorance on the part of a neighbor is a fault that I carefully nurture if he is an enemy and most readily forgive if he is a friend.

What am I then to think of Mr. Neuhaus? First, I might suggest that, when he rests his eyes on the banks of the Ottawa and wishes to write, he should turn to a genre other than social comment. His adherence to rules of evidence is much too relaxed when he is in such circumstances. He might also pay some attention to studies of nationalism. Not all nation-building follows the same path, nor fulfills the same needs, nor meets the same challenges. (Not all nations, for instance, become one largely through the proclamation of a doctrine addressed to themselves and to the rest of the world.) He might also reexamine yet once again, alas, the case of those critics who charge that there is a strange blindness common among U.S. social scientists and moral prophets. Their science is sophisticated and their hearts pure; they rush, therefore, to think Americanly and benevolently about the rest of the world; again and again they are met with at best an ambivalent response that creates a hurt and opens a gulf. But look at it from our point of view: We do not like always being invited to be friends on your terms.

Such reflections, I realize, are fairly trite. They have another great disadvantage: They usually launch many non-Americans into anti-American intellectuality, and quite a few American intellectuals into fits of self-doubt. There is no health in these kinds of mental joyrides. So 1 cannot derive any pleasure from my concluding reflections. I will, therefore, make my final point in more personal terms. It does little honor to $\mathrm{Mr}$. Neuhaus to publish in Worldview a piece which uses the information and the tone he has chosen. His humor turns too quickly into sarcasm. It is not funny to see him poke fun at all our political life. His own ties to the country are no excuse. These ties are the accidental ones of birth and upbringing. The ties of affection that he feels are nostalgic and sentimental, it seems to me. The group of people one really loves is the one with whom one lives the struggles of one's maturity.

\section{Professor of Religion \\ Concordia University \\ Montreal}

Richard John Neuhaus Responds:

M. Despland's splendid and chastening letter highlights once again the dangers in trying to be funny. I find myself in a "damned-if-you-do/ damned-if-you-don't"' dilemma similar to the one Despland says he is placed into by my remarks on Canadian thought being "reactive." That is, if I take up Despland on his arguments, I might be accused of giving the lie to the whimsical intent I attribute to the original article. Ah well, like Despland, let me muddle on in the hope of breaking out of the dilemma, if only by chance.

M. Despland's correction about Newsweek hardly seems substantive. By whatever name, "tax privilege" is the power to control, in this case to control competition. As for the pressures to learn French, the distinction between "social reward" and "legal coercion" is fragile at best. The point is that, and in part because of the law, if you want to get ahead you better learn French, also in Saskatchewan. As to the schools, there is nothing wrong with the law favoring one language over another. The "democratic notion" is that people ought to be able to choose for themselves and their children, a right sharply inhibited by Bill 22 in Quebec. I agree wholeheartedly with $M$. Despland that the desirable alternative is definitely not the "totalitarian" school policy that still prevails in the United States. Contra Despland, I reserve the right to "really love" both Canada and the United States, for it is among both peoples that I am living out the struggles toward maturity.

Finally, and for what little it may be worth, I suspect $M$. Despland and I are not so far apart. His return address, I note, is a boulevard named Maisonneuve (new house, Neuhaus).

\section{Food Enough for All?}

To the Editors: I have just read the September, 1975, Worldview article "Food Enough for All" by David Harmon and Marylin Chou and must make the following comments:

1. Harmon/Chou appear to have written their article within the sterile confines of Croton-on-Hudson. I refer particularly to their paragraphs about the so-called successful Philippines' " Masagana 99" program. Their recitation of Marcos's New Society data is theoretically profound but realistically naive.

A closer look at the current Philippine scene would indicate that the proposed Land Reform program brought about by Marcos's New Society is a boon for sugar plantation owners. Land much needed for rice and other crops is being used for expanded sugar fields-at low yields for the grower and even less usable food for the average Philippine citizen.

Had Harmon/Chou taken seriously the plight of the Philippine citizen, they would know that even the price of rice is getting further and further beyond the reach of these good folk.

2. My point is simply this: that Harmon/Chou fall victim to the false hope that "profit" will enable an abundance of food for the world. It is not working so in the Philippines, nor is it for the rest of the world.

The first and most important incentive for food production is not profit but the sacredness and beauty of human life. When these factors are relegated to second place, we will simply not be able to deal realistically with the problem of food production.

The gap between rich and poor continues to widen. So does the gap between researchers and realism.

North Point, Hong Kong

$$
\text { Ewing W. Carroll, Jr. }
$$

David P. Harmon, Jr., and Marylin Chou Respond:

Let us start with Mr. Carroll's second and more important point, that "profit" offers false hope. One of the key requirements in developing-country 